\title{
Challenges in Inclusive Education: Multi Lingual Education in Elementary Schools of Andhra Pradesh, India
}

\author{
Bharath Bhushan Mamidi \\ Centre for Action Research and People's Development, India
}

\begin{abstract}
Mother tongue based education in early childhood and early primary school year is critical to the promotion of world's languages and cultures. The Right to Education Act 2009 and the National Policy for Children 2013 explicitly prioritize education for disadvantaged groups by creating an enabling environment through necessary legislative and policy measures and provisions. This paper is based on a study undertaken by the author to identify inclusive and exclusionary practices in government schools with special reference to teaching in mother tongue and multi-lingual education in schools in inter-state border areas of Andhra Pradesh. The study identified sample schools from inter-state border districts where exclusionary practices are assumed to be posing greater challenges owing to a host of other conditions like diverse linguistic communities, poor infrastructure facilities, and low access to opportunities of college education, amongst others.
\end{abstract}

Keywords Inclusive School, Indigenous Languages, Linguistic Minorities, Mother-tongue Education, Multilingual Education

\section{Introduction}

School data of Andhra Pradesh for 2012-13 reveals a very high drop out among the Scheduled Tribes, who are most marginalised and demand attention from the programmes of inclusion. Elementary level (class I-VIII) dropout rate of the state in 2012-13 was at $26.48 \%$, with $29.58 \%$ among Schedule Castes and 53.64\% among Scheduled Tribes. Learning in a language other than one's mother tongue is one of the barriers to inclusive education.

Similar patterns of high dropout rates among the ST students are seen at Secondary level (I-X). While the dropout rate is $37.82 \%$ for all categories, it is $41.48 \%$ for Scheduled Castes, and $67.96 \%$ among Scheduled Tribes. High dropout rate among certain social categories is believed to be a result of differences in language, alien curriculum (Devasena 2007, Narender Reddy 2014), social adjustment problems, poverty, migration, domestic work and practice of child labour (Lingaiah and Ashok 2010).

Table 1. Dropout Rates of Boys and Girls at Secondary Level (2012-13) in Andhra Pradesh

\begin{tabular}{|c|c|c|c|c|c|c|c|c|c|}
\hline \multirow{2}{*}{ Level } & \multicolumn{3}{|c|}{ Boys } & \multicolumn{3}{c|}{ Girls } & \multicolumn{3}{c|}{ Total } \\
\cline { 2 - 11 } & All & SC & ST & All & SC & ST & All & SC & ST \\
\hline I to V & 15.13 & 14.69 & 29.87 & 15.45 & 15.14 & 34.19 & 15.29 & 14.91 & 31.99 \\
\hline I to VIII & 27.14 & 30.02 & 52.30 & 25.81 & 29.14 & 55.04 & 26.48 & 29.58 & 53.64 \\
\hline I to X & 37.83 & 41.80 & 67.01 & 37.80 & 41.15 & 68.94 & 37.82 & 41.48 & 67.96 \\
\hline
\end{tabular}


Field study comprised 24 schools from six mandals ${ }^{1}$ of three districts viz., Nellore, Srikakulam and Kadapa of Andhra Pradesh. The sample districts represent a range of situations like diverse cultural context of the communities, diverse languages spoken by the inhabitants owing to location (inter-state border).

\section{Context- Inclusive School}

Education 'consists of a methodical socialization of the younger generation' (Durkheim, 1922). Education comprising deliberate inculcation, transmission of values, norms, culture, behavioural patterns and socially accumulated knowledge, assumes increasing importance as societies grow larger and more complex, and increasingly depend upon literacy and access to schooling.

Education as an important institution of socialization requires direction, control and authority and is defined by the state that controls political leadership and endowed with 'the final power of coercion' (Mac Iver and Page, 1949) and indeed 'use of physical force' (Gerth and Milks, 1947). The extent of distribution of education and consequences following it (nature of job, incomes, social statuses etc.) is an indicator of the nature of society (democratic or rule by minority) and a tool differentiating the privileged from those who are not. The school system also reflects the inequities and stratification of the larger society, and becomes the site for contradictions and conflicts of the society.

National Policy on Education - 1968 recommendation to build a National System of Education based on the Common School System, reflects the nature of the state to promote class stratification in school education. (Sadgopal A, 2014). The right of children to free and compulsory education (RTE) Act, 2009 not only provides for free and compulsory education to all children in the age group of six to fourteen years, but also envisages equal opportunities to all to flourish in life to their full capabilities.

Children from marginalised and vulnerable communities inherit limitations in enjoying their right to survival, development, protection and participation. These constraints are reflected in their access to the type of education and schools to begin with and their chances of continuing education to their desired level. However, in recognition of these constraints experienced by certain communities, the Constitution of India promised that the state shall 'provide with special care education and economic development to Scheduled Castes (SC) and Scheduled Tribes (ST)' (Article 46) support education among religious and linguistic Minorities (Article 30).

\section{Features of Exclusion in School System}

Currently, school in India is seen facing a serious crisis.

1 Mandal refers to a cluster of villages, a sub-district administrative unit
Anil Sadgopal outlined a five-fold agenda of Jomtien Declaration that includes making education "a commodity that can be traded in the global market and offered for WTO negotiations", promoting "parallel layers of inferior quality education for various sections of society, thereby becoming a multi-layered school system" which denies "quality education to the under-privileged masses lacking capacity to pay", reject access to free elementary education as a human right or fundamental right (Sadgopal, 2006). Advocates of Free and Quality Education for All insist a publicly funded Common School System based on neighbourhood schools and "the struggle for building the Common School System is simultaneously a struggle for epistemic and social transformation as well."

Educational exclusion as a form of social exclusion has its roots in exclusive policies and practices. Govinda and Bandyopadhyaya (2008) identified exclusion in the education system in India which is reflected in varied forms that include denial of access to school, constraints in remaining in the school and progressing to higher levels of education due to structural constraints and limited opportunities as well as 'silent exclusion'.

Young Lives research highlights hidden inequities in enrolment as well as achievement levels across public and private schools and perpetuation of inequalities through introduction of poor quality schools for the children from poor households. Findings of the Young Lives study, based on 3000 children and families in Andhra Pradesh from 2002 to 2010-11, indicates "a growing shift towards private schooling, not only in urban areas but also across rural India, where low-fee private schools have mushroomed, carrying the fashionable tag of "English-medium" (Young Lives, 2013). Young Lives study recommends that interventions aimed at ensuring Education For All (EFA) must go beyond mere universal enrolment and emphasis on 'common school system' to ensure that the education system promotes equity and social justice.

Studies also revealed students of Telugu medium as mother tongue, despite facing odds, performed significantly better than their English medium counterparts at the primary level in Telangana and Andhra Pradesh. Sree Kumar Nair's study, based on Young Lives longitudinal data of primary school children in both the States, analysed the potential link between medium of instruction and student performance at primary school level using Math scores as proxy for student achievement and cognitive development while taking into account various socio-economic factors. The study concluded that "introducing English as medium of instruction at earlier grades in the school might negatively affect learning outcomes" (Mallikrajun, 2015).

Problems of linguistic minorities have received attention of the Andhra Pradesh legislature as well. A Joint Legislature Committee with A. Chakrapani as Council Chairman's report in 2012 reviewed the status of Telugu medium schools run in Orissa, Tamil Nadu and Karnataka states. The committee observed the need to help Oriya, 
Tamil and Kannada medium schools run in Andhra Pradesh. The Committee recommended exclusive Telugu medium schools in Telugu speaking areas of Orissa state. Besides, it recommended that the Tamil Nadu Government to fill up the vacant Telugu teachers' posts and establish Telugu medium schools in six districts including Chennai (The Hindu, 2008).

Exclusion of tribal languages and teachers' negative attitude towards tribal dialects is seen as partly responsible for low performance and high number of out of school children (Nambissan, 1994). Besides, teachers have a low opinion of the language of economically and politically disadvantaged communities. The child learning in a "foreign language" starts growing with a barrier. Negative implications of neglect of local languages have been viewed as a process of cultural dominance by the 'National Focus Group on Problems of Scheduled Caste and Scheduled Tribe Children' (Jha and Jhingram, 2005).

\section{Inclusive Education - Children of Minority Languages in Andhra Pradesh}

According to the UNESCO definition, "inclusive education" or "inclusive learning" refers to the inclusion and teaching of ALL children in formal or non-formal learning environments without regard to gender, physical, intellectual, social, emotional, linguistic, cultural, religious, or other characteristics (UNESCO, 2004). Inclusive education not only refers to the inclusion of marginalized groups, but also "culturally responsive" education and culturally responsive pedagogy based on learning experiences sensitive of the cultural realities of the child (e.g. home life, community experiences, language background, belief systems) (UNESCO, 2004). Such an approach to inclusive education requires restructuring policies, curricula, cultures and practices in schools and learning environments so that diverse learning needs can be met (Patton, 2011). Such an approach enables the school to adapt to the needs of the children rather than coercing the children to adapt to the school.

Rajiv Vidya Mission (RVM- SSA) of Government of Andhra Pradesh (GOAP) adopted the approach wherein "Inclusive education means that all students in a school, regardless of their strengths or needs in any area, become part of the school community". Inclusive education was initially considered a major issue with regard to the children with special needs. Issue of inclusive education has received considerable attention due to the RTE and many measures have been introduced from time to time. Further, the Section 29 (2) (f) of the RTE Act provides that the medium of instruction shall, as far as practicable, be in the child's mother tongue. Mother tongue includes dialects and languages that may or may not have a script and spoken by large or small population.

Barriers to inclusive school and what is expected out of the school is greatly influenced by the dominant cultures of education. At the macro level, these practices are resulting in the popularisation of English as the superior language and the language of success and growth. In Andhra Pradesh, it is reflected in many Telugu speaking households preferring to send their children to English medium schools.

Forcing the child to learn in a language that is not one's mother tongue, the child is made doubly disadvantaged by eliminating the child's worldview, child's culture, folklore, mythologies and lifestyles from the textbooks. An absence of the child's worldview in the textbooks compels one's disassociation from all that is one's own and fosters a culture of disempowerment. Teachers' preconceptions, biases and behaviours, subtle or overt, conscious or unconscious towards the 'hidden curriculum' becomes a means of unnoticed discrimination against children of $\mathrm{SC} / \mathrm{ST}$ background (Kumar, K, 1989).

Several studies indicate that beginning education in the mother tongue and gradually building competence in the second language is critical to fostering educational success of children of minority languages. Multilingual education (MLE) reduces the linguistic and cultural barriers faced by students when entering school (MacKenzie, 2009).

Constraints faced by ST children studying in a different language are noticed by recent studies in Andhra Pradesh and that absenteeism of ST children is also due to the problems of comprehending Telugu which is not their mother tongue (Lingaiah and Ashok, 2010). An inclusive school needs to be responsive and sensitive to the local cultures and languages since the child's learning process is shaped by formal and informal forces (Devasena, 2007). Innovative teaching method like MLE method is a great need for primary schools of ST children. Use of local language and examples from the child's daily world and culture makes the TLM more effective (Narender Reddy, 2014). Studies on the role of teachers in MLE recommend that teachers familiar with local languages are more effective in helping the learning process among the children (Hari Prasad, 2005).

\section{Other Forms of Barriers}

Lack of infrastructure and adequate teachers to ensure quality education is also a major barrier for inclusive education. Poor quality of education is reflected in several children by dropping out of school or shifting towards private schools or 'budget schools'. Result of this twin phenomenon is the cause of schools having far less students to run the schools. Growing shift towards 'private education' is a matter of grave concern, because the government schools are increasingly becoming abandoned. According to ASER data 2014, the exodus to private schools is across states with low or high enrolment in private schools.

One of the responses of the government to this crisis is 'rationalization' of these schools, which is closing down or merging these "underperforming" schools. After the implementation of RTE Act in April 2010, about 1 lakh schools have been closed down across the country. Majority of the government schools in Andhra Pradesh, according to a recent study by NGO network, lack basic infrastructure and 
sufficient staff (APACR, 2014). About 9 million children studying in 76,467 government schools with infrastructure of only 279,615 class rooms means many rural children are studying under the trees, according to this report.

\section{Inclusive Education - Children of Local dialects and Languages: Experiences of Andhra Pradesh}

Education for ST students is a special focus area to the Sarva Shiksha Abhiyaan (AP). One of the key concerns pertains to mother tongue-based education to effectively address barriers to inclusive education for the tribal children. As part of measures for the special focus groups ${ }^{2}$, the textbooks are prepared in the mother tongue, in the script of the regional language, for ST children, at the beginning of primary education, who have a language distinct from the regional language. The approach adopted by the SSA-AP includes multilingual education as a part of the 'Quality Initiatives'. As part of the pilot project, textbooks were prepared in 2003 for eight major tribal communities of the state viz., Adivasi Oriya, Banjara, Gondi, Kolami, Konda, Koya, Kuvi and Savara (Multilingual Education, Working Group- Asia Pacific, 2009). The pilot project implemented in 220 schools was expanded gradually to cover 3000 schools covering 80,000 children. It was the largest experiment of its kind in the world and considered a global best one (Sujatha, 2012).

Objectives of the SSA-AP interventions in MLE include the following:

- To develop appropriate cognitive and reasoning skills

- $\quad$ To enable smooth transition from Mother Tongue (MT) to L2 (State) L3 (National) languages.

- $\quad$ To enable them to know more about their culture and community

- For a number of reasons education, which utilizes local languages and cultures, is beneficial both to individual and to communities

Impact assessments of the use of tribal dialects for elementary education revealed many positive aspects and also areas for further action to consolidate the experiences and strengthen the approaches with better monitoring and support systems. The recommendations and findings made by these studies hold good even today. With the RTE placing emphasis on mother tongue based education from Class I onwards, the process of learning, preparation of curriculum, and innovation and implementation of the entire process needs special attention to ensure that the tribal child is not denied the right to education in mother tongue (GOAP-SSA, May 2014).

Role of language as a major factor in addressing barriers to inclusion is also highlighted by the State Level Achievement Survey in Andhra Pradesh (SLAS- AP). Achievement levels of children of Classes III and VIII indicated highest mean score for Telugu and lowest mean score for mathematics. Continued highest score for Class III and Class VIII for Telugu indicates the role of language in learning achievements and also the influence of home, the surroundings and daily life interactions which constitute the $24 X 7$ school of any child.

The SLAS 2014-15 Report revealed that overall achievement levels of Class VIII students in the state for five subjects had a mean value of 47.7. The highest mean score was $54.6 \%$ in Telugu and the lowest of $29.2 \%$ in mathematics. Overall achievement levels of Class III students for four subjects had a mean value of 17.1. Among the four subjects, the students scored highest in Telugu $(20 \%)$ and lowest in Mathematics (15.1\%). Students showed very poor results in English and Maths - subjects which are considered very essential for development of important life skills (communication and calculations) and also for success in higher education and professional endeavours (GOAP-SSA, 2015).

Table 2. Overall Achievement Level of Class III and Class VIII students for all subjects in 2014-15

\begin{tabular}{|c|c|c|c|c|c|c|}
\hline Class & Telugu & English & Maths & $\begin{array}{c}\text { Env } \\
\text { Sci }\end{array}$ & Social & Overall \\
\hline Class III & 20.0 & 15.6 & 15.1 & 17.5 & & 17.1 \\
\hline Class VIII & 54.6 & 42.4 & 29.2 & 30.5 & 32.7 & 47.4 \\
\hline
\end{tabular}

Source: SLAS 2014-15 page 6 and 12

Key features of inclusive education for children of local dialects and languages:

- Education in mother tongue for the students from tribal communities or linguistic minorities helps identify and harness the strengths of the child;

- Helps makes education relevant and customized to meet expectations of each child and ensure full opportunity to participating in the life of the classroom;

- Helps enlist child's parents in their education and in the activities of the school.

\section{Reflections from Field Study- School in a Challenging Context}

Growing shift in parents' perception about private schools and English medium schools as better options to government schools is one of the challenges faced by government schools. Diverse needs of multi-lingual students pose another challenge to inclusive education. Quality of education is affected by all these factors. Yet, these schools fulfill the educational needs of the poor households. In the absence of these government schools, a large section of the children would undoubtedly be out of school. The social context in which government schools operate and also the constraints and barriers they negotiate with are discussed from the data collected through the field study. 


\section{Inclusive Education for Linguistic Minorities}

GOAP policy with regard to linguistic minorities in the areas covered by field study provides evidence of response to the special needs of the children speaking Oriya, Savara and Tamil. Elementary education to the linguistic minorities is ensured through two approaches viz., access to free elementary education in the border areas, and education in mother tongue of the linguistic minorities.

Schools in the inter-state border areas have disadvantages of being in locations that are poor in educational resources and transportation facilities, and being complex with multiple linguistic demands. The very access to schools beyond Class V or Class VII, irrespective of the medium of instruction, is limited. Limited number of high schools and junior colleges act as a barrier. Presence of schools in these inter-state border areas plays an important role of preventing child labour, early marriages and illiteracy.

Government schools are the only source of education for the children of Savara tribe of Srikakulam. Similarly, government schools are the exclusive source for Oriya speaking linguistic minorities in Srikakulam as there are no private schools in Oriya medium. In contrast, Tamil community in Tada mandal has access to several private Tamil medium schools. There are also schools across the border where the children from border villages of AP commute to study in the mother tongue.

The sample mandals have 3 to 13 government high schools each and four mandals have one or two residential educational institutions or Kasturba Gandhi Balika Vidyalaya (KGBV). Junior colleges, private or government, are very limited in these mandals. There is no junior college in Tada mandal of Nellore district. Many schools have been upgraded last year to the next higher class.

"How far can we expect the child to study, when there is no college anywhere in the mandal. Studying till high school is all that we can think of. That doesn't help my child to get any job. I can't send my child to district headquarters" (parent from Ramapuram village in Nellore).

Government response to education in mother tongue varies across the districts of the field study. MLE response is active with regard to Oriya and Savara languages. There is no MLE intervention with regard to Tamil.

\section{Basic Infrastructure of the Schools and Incentives}

All children have free education without fee for tuition or exams. Mid-day meals, text books and two school uniforms are provided to every child. Inadequate infrastructure is a major constraint in making schools attractive for the children. School buildings are designed for multi-grade class room teaching. For instance, Kadiritippakandrika PS has 30 students from class I to $\mathrm{V}$ and three teachers. The school has two rooms, toilets are not functional and there is no facility of drinking water.

Karuru Primary School of Tada mandal in Nellore has 29 children enrolled. It has a single teacher and a Vidya Volunteer appointed in November 2014. Very few children of the 4000 odd population of the village attend this school. Most of the children go to Tamil medium school. There is a government school and a private school at Arambakkam in neighbouring state, about $2 \mathrm{kms}$ from the Karuru primary school.

Table 3. MLE interventions vis-a-vis different linguistic minorities:

\begin{tabular}{|l|l|l|}
\hline Minority language & Government schools & Private schools in the region \\
\hline Savara tribal language & $\begin{array}{l}\text { Savara text books as a bridge language to Telugu } \\
\text { medium. Although the text books are available in } \\
\text { Savara, they are hardly used. They are Telugu } \\
\text { medium schools in practice }\end{array}$ & $\begin{array}{l}\text { No private schools offer Savara medium in Bhamini and Kottur } \\
\text { mandals of Srikakulam. }\end{array}$ \\
\hline Oriya & Oriya medium schools & $\begin{array}{l}\text { No private schools offer Oriya medium in Bhamini and Kottur } \\
\text { mandals of Srikakulam. }\end{array}$ \\
\hline Tamil & Nil & $\begin{array}{l}\text { There are private Tamil medium schools in Tada mandal of } \\
\text { Nellore, besides government and private schools across the } \\
\text { border in Tamil Nadu. }\end{array}$ \\
\hline
\end{tabular}




\section{Multi Grade Teaching}

Multi grade teaching is the practice across all schools. Many students are engaged in passive learning (reading or writing) while the teacher is interacting with one batch of students in the class. More than half the time of the day the child does not interact directly with the teacher. School curriculum begins with language and gradually introduces the subjects. Details of class wise subjects of Telugu medium schools are furnished below.

Table 4. Subjects covered by class

\begin{tabular}{|l|l|}
\hline Class & Subjects \\
\hline Class I \& II & Telugu and English \\
\hline Class III, IV, V & Telugu, English, Maths, Environment Sciences \\
\hline Class VI, VII & $\begin{array}{l}\text { Telugu, English, Maths, Environment Sciences, } \\
\text { Hindi, Social Studies }\end{array}$ \\
\hline
\end{tabular}

\section{Low Attendance}

Problem of low attendance after the vacations varies across the districts. It is also because of the cultural events and festivals of the linguistic minorities that are different from the school calendar of the state. The problem is serious in areas like Tada where the children tend to visit their relatives across the borders or spend time with neighbouring Tamil families whose Tamil Medium schools have holidays on different days. Similarly there is low attendance of children of Oriya community in Bhamini mandal of Srikakulam during the Oriya festivals. As a result, the Tamil and Oriya speaking children have 'additional vacations' whenever the schools of neighbouring state have vacations.

\section{Upgradation of the School}

There are pressures from the community to upgrade the school so that children could study further without having to commute to the next school at a distance. The pressures for upgradation are high in primary schools and upper primary schools. The parents of the girls are more particular to send the children to the local school itself.

Many schools in the field study have been upgraded for the next class during the year 2013-14; from class VII to class VIII or from class V to VI. Not all schools are fortunate to get upgraded, especially if the strength is low. Some of the Oriya bilingual schools in Srikakulam wish their schools get upgraded because the children have to commute long distances to study the next class. Since there are not many Oriya medium UPS or high schools nearby, many Oriya medium children are gradually moving to Telugu medium schools in primary school itself. For this reason, the school teachers plan to upgrade the school quickly, to avoid this shift. The teachers fear if the trend continues there will be fewer students in the Oriya medium schools in future.

\section{Special Efforts by Teachers to Make Schools More Attractive}

Teachers in the study area have been trying different methods to make schools more attractive. Field study revealed varied measures initiated by the teachers to enlist community cooperation and children in extracurricular activities. Some schools are getting integrated with the Anganwadi to ensure the habit of going to school from early stages of childhood.

Telugu is taught in Oriya medium schools of Srikakulam district so that students find it convenient to study in their mother tongue although gradually shifting to Telugu medium schools. Introduction of Telugu in class II is a choice of the teachers and students as there are no exams conducted for this paper.

\section{Teacher's Knowledge of the Local Language}

Teachers' knowledge of the local languages is critical since the inter-state border areas have multiple languages. Sometimes non-Telugu languages are the major or the only language the local inhabitants speak.

All teachers have knowledge of Telugu, which is the language they have studied in school and college. Telugu is also the language they had for Teacher Training or Bachelor of Education courses. The regular correspondence with school authorities and other stakeholders is also carried out in Telugu.

Oriya bilingual schools have teachers who can speak and conduct classes in Oriya. Teachers working in interstate border areas of Nellore have no knowledge of Tamil although that is the only language the children or their parents speak in some villages bordering Tamil Nadu. These teachers face serious barriers in communicating with the children. Teachers in tribal schools of Bhamini mandal, Srikakulam are not using the Savara language for classroom transactions, although two teachers can speak Savara.

Orientation and special skills are required for the teachers engaged in teaching linguistic minorities. Most of them have not received any training in MLE. None of the teachers have received any training to teach linguistic minorities or tribal dialects.

Many teachers working with communities that speak a different language reported that they face problems of communicating with the students and their parents. This problem is most frequently seen in Nellore where the students and their parents speak Tamil and the teachers do not. Six out of eight teachers in Nellore reported problems of not understanding the needs of the students and also difficulties in conveying effectively to the students. There is no common language between the teachers and students in Tamil speaking schools of Tada mandal in Nellore. The problem is less among teachers in Oriya medium and Savara schools since most of these teachers speak the local language. Language barriers of teachers while attempting to effectively 
explain concepts, have been reported by six out of 24 teachers. TLM like radio lessons, audio visual material, etc is also not available in local languages compared to Telugu.

\section{MLE in Practice- Oriya and Savara Languages in Srikakulam}

Srikakulam district has a significant population speaking Oriya and Savara tribal languages. The three-language policy in border mandals of Srikakulam offers Oriya, Telugu and English. Earlier the three-language policy included Hindi, which is currently replaced by Telugu. Oriya medium schools have Oriya and English from class I, while Telugu is introduced from class VI.

There were 11,953 students in Oriya medium schools in Srikakulam district during the year 2014-15. There were 575 Oriya language teachers in 305 schools covering these 11,953 children.

MLE programmes for Oriya linguistic minorities are an inter-state collaborative exercise with government and non-governmental organisations promoting state efforts. Syllabus in Oriya medium is similar to the Telugu medium schools. There is a Deputy Inspector of Schools for Oriya medium schools in Srikakulam district. There are 6 Oriya medium schools also in Vizianagaram, Visakhapatnam, West Godavari and Guntur districts. While the Odisha government provides Oriya language text books, the AP government translates all other syllabus books into Oriya. There are major delays in these processes and change in state syllabus creates further delays. Non language text books translated into Oriya are made available from August to November, while the schools open in June. Without translated textbooks, the progress depends on the teacher's ability to translate into Telugu, which also takes away a lot of time from teaching. The problems are worsened if there are not enough teachers. For instance, the Katragada school has only one teacher, supported by a Vidya Volunteer, appointed from October with a salary of Rs 5000 p.m. There are two volunteers supported by Utkal Sammelan with an honorarium of Rs 1000 p.m.

There are more bilingual elementary schools (50) compared to Upper Primary (13) or High Schools (23) in the district. Class wise enrolment in Oriya medium schools indicates a significant fall from Class VI, since not all Oriya medium students have Upper Primary Schools in the neighbouring areas (see Fig.1).

Shift to Telugu medium schools is not an easy transition for many children. Of 1069 children who appeared for Class $\mathrm{X}$ test in the district during 2013-14, 107 students failed in Telugu language.

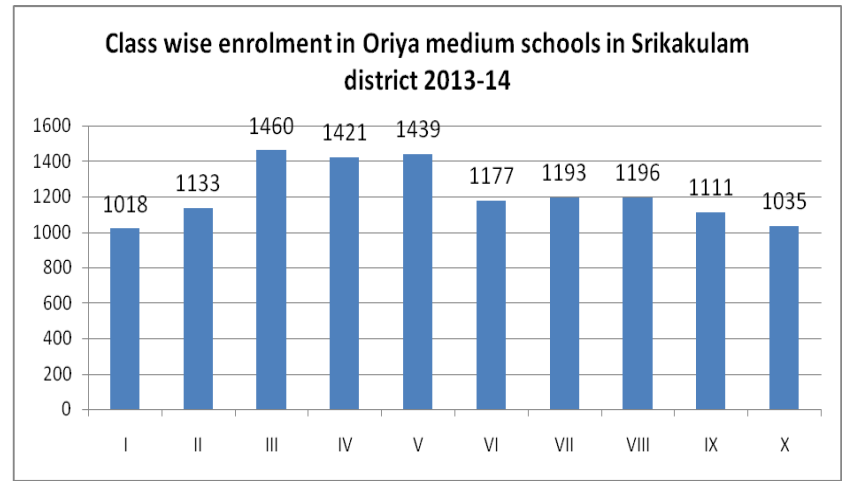

Figure 1. Class wise enrolment in Oriya medium schools in Srikakulam district 2013-14

Number of Oriya medium schools in the district is declining, and the Oriya speaking students are either shifting to Telugu medium schools from Class VI or joining Telugu medium schools from Class I itself to avoid difficulties of language transition at an advanced stage. Until a few years ago there were 7 Oriya medium schools in Bhamini mandal of the district. Now there are only 3 schools. Many Oriya children are studying in Telugu medium school in Liviri village although there is bilingual school there because they have to travel $15 \mathrm{kms}$ to continue further studies in Oriya medium at Batthili.

\section{Liviri MPUPS}

Liviri MPUPS is a bilingual school in Bhamini mandal. Liviri IV Ward has population of 1167 Oriya speaking households. The school started initially as an Oriya medium school and the Telugu medium was added later on. Telugu medium school is up to Class VIII and Oriya medium school is up to Class V, with 129 and 48 students enrolled respectively in each media. Telugu medium school is upgraded to Class VIII, while Oriya medium school is up to Class V.

The bilingual school has both Telugu medium and Oriya medium schools. There are altogether 9 teachers allotted for the school with strength of 177 children enrolment. A Mathematics Assistant teacher post is vacant, and 8 teachers include 2 SGT Oriya, 3 SGT Telugu, 2 SGT Pandits (1 Hindi and 1 Telugu) and a SA Social Studies. Oriya medium school has two Oriya SGT teachers. All the children of Oriya medium school sit in one class room.

"Multi grade teaching is not the right method. Each Class must have a teacher to engage the students actively in teaching-learning process all through the working hours in the school, because the time taken for teaching the Class is same whether there are a handful students or full strength. While you are teaching one group of students in a Class room other children have to sit idle or engaged in passive ways like giving them reading or writing work," explained the class teacher. 
Table 5. Enrolment and attendance of students in both medium of Liviri MPUPS in 2015

\begin{tabular}{|c|c|c|c|c|c|c|}
\hline \multirow{2}{*}{ Class } & \multicolumn{2}{|c|}{ Oriya medium } & \multicolumn{2}{c|}{ Telugu medium } & \multicolumn{2}{c|}{ percentage of students present in } \\
\cline { 2 - 7 } & Students enrolled & Students present & Students enrolled & Students present & Oriya medium & Telugu medium \\
\hline I & 7 & 7 & 12 & 7 & 100 & 58.3 \\
\hline II & 9 & 8 & 11 & 4 & 88.9 & 36.4 \\
\hline III & 8 & 7 & 22 & 11 & 87.5 & 50.0 \\
\hline IV & 16 & 14 & 15 & 11 & 87.5 & 73.3 \\
\hline V & 8 & 7 & 12 & 8 & 87.5 & 86.7 \\
\hline VI & & & 17 & 14 & & 82.4 \\
\hline VII & & & 22 & 18 & & 81.8 \\
\hline VIII & & 43 & 129 & 87 & & 77.8 \\
\hline Total & 48 & & & & & 67.4 \\
\hline
\end{tabular}

Oriya medium schools are neglected for varied reasons. There is no replacement or in-charge teacher provided when one of the two teachers are on leave. Problems and needs of these schools are not included in the School Development Plan. These teachers are not consulted in any policy matters. There is no separate meeting of the parents for Oriya medium schools.

Oriya speaking population in the habitations around Liviri is big enough to feed an Oriya medium high school. Since there is no Oriya medium school up to Class X, many children join Telugu medium school.

\section{Choice or Compulsion- Studying in a Language that's not your Mother Tongue}

Choice of a medium of instruction is affected by many factors llike access to the medium of first preference, opportunities of continuing further studies in the same medium, and the language preferred in selection for government jobs. Sandhya, for instance, of Class VII in Liviri MPUPS is studying in Telugu medium although Oriya is her mother tongue. Her father, a mason, migrated to Hyderabad and Chennai, so she studied in Telugu and English medium schools up to Class III. On returning to her village she joined Telugu medium school and finds the transition very difficult.

Many of the Oriya households feel it is difficult to study in their mother tongue because, there are not many schools nearby. Besides, they believe that it is better to study in Telugu medium to be selected for government jobs or to compete well with others trying for government jobs.

"What jobs we would get by learning in Oriya medium? Will any parent feel safe to send their daughter to a far away place to study in Oriya medium school? We thought it is better for our daughter to study in whatever medium that is within our reach", explained Smt Savitri.

\section{Batthili Primary School}

Batthili Primary School, a bilingual school, was established on October 18, 1895 by DEO of Ganjam. The school is gradually changing into a Telugu medium school.
Oriya is the mother tongue of about one fourth of the students of Telugu medium school. Some families send their children across the border to live with their relatives and study in Batthili. Some of the Savara ST children are also studying in Oriya medium. There is Oriya medium UPS, High School and Junior College at Batthili. There is also a hostel for girls and boys at Batthili. Some of the households are sending their boys to private schools or Telugu medium government school. However, the girls attend Oriya medium schools.

The school has 126 children in Oriya medium and 123 in Telugu medium from Class I to V. The school has three teachers and a Vidya Volunteer in Oriya Medium. The teachers conveyed the need for two more teachers to the Deputy Inspector of Schools, but no action has been taken since 2013.

Table 6. Distribution of students by Oriya and Telugu media

\begin{tabular}{|c|c|c|c|c|c|c|}
\hline \multirow{2}{*}{ Class } & \multicolumn{3}{|c|}{ Oriya medium } & \multicolumn{3}{c|}{ Telugu medium } \\
\cline { 2 - 7 } & Boys & Girls & Total & Boys & Girls & Total \\
\hline I & 6 & 10 & 16 & 9 & 9 & 18 \\
\hline II & 2 & 12 & 14 & 10 & 12 & 22 \\
\hline III & 8 & 22 & 30 & 12 & 14 & 26 \\
\hline IV & 10 & 27 & 37 & 12 & 21 & 33 \\
\hline V & 8 & 21 & 29 & 10 & 14 & 24 \\
\hline Total & 34 & 92 & 126 & 53 & 70 & 123 \\
\hline
\end{tabular}

Problems of teachers from schools teaching local dialects:

- Oriya teachers have limited or nil teaching -learning material in Oriya. Since the question papers do not arrive on time, the teachers can translate only partially. "It takes long time to write the whole question paper on the black board. Figures and illustrations in the question paper cannot be written on the black board" explained a teacher

- Teachers are not trained to address needs of teaching in a local dialect. "Routine two day training is not helpful to deal with practical needs on the ground", said a SGT Oriya teacher 
- TLM is not made suitable to Oriya language. For instance charts supplied by Government of Andhra Pradesh are in Telugu.

- Training as well as Handbooks given to the Oriya medium school teachers is also in Telugu

- There is no text book for Class III Mathematics. Teachers have to buy or photocopy the textbooks when not received on time

- Children have no textbooks to refer to, even though the teachers have verbally translated the Telugu material

- Students of Oriya medium have less access to Bridge Schools, Model School and KGBVs since these schools do not have options of Oriya language

- Oriya children have limited educational opportunities because all other sources of information in the neighborhood are in Telugu

- $\quad$ Oriya medium does not have radio classes since all are in Telugu

\section{MLE in Savara Tribal Language}

GOAP has provided a curriculum based on National Curriculum Framework 2005 in Savara language up to Grade 5 (textbooks and other materials such as local stories). MLE, initiated in 2004 through Savara, has an integrated theme-based approach in the early years with subject based textbooks. The second language (Telugu) is introduced gradually, starting in grade 2 , orally at first, then written.

Table 7. Enrolment in Nallaraiguda school

\begin{tabular}{|c|c|c|c|}
\hline Class & Boys & Girls & Total \\
\hline I & 11 & 7 & 18 \\
\hline II & 29 & 15 & 44 \\
\hline III & 11 & 6 & 17 \\
\hline IV & 15 & 9 & 24 \\
\hline V & 6 & 7 & 13 \\
\hline Total & 72 & 44 & 116 \\
\hline
\end{tabular}

Nallaraiguda Government G.P.S (T.W) School in Bhamini Mandal was established in 1987. It has 116 children enrolled ( 72 boys and 44 girls). The village is inhabited by Savara tribe. The school has allotment of three teachers. There is Head Master and a Vidya Volunteer belonging to Savara tribe. Head Master is SGT appointed in 1986 with Class X and TTC qualifications. One teacher went on transfer in November 2014, another teacher went on deputation in June 2014. Vidya volunteer was appointed on 21 November 2014.

Number of students present was 36 out of 54 students enrolled in Class III, IV and V. Only 7 boys said they like English most, compared to 20 boys who liked Telugu.

Ease and involvement in mother tongue compared to Telugu was checked by asking the students to narrate a story in their mother tongue and later to tell the same story in Telugu. Students were spontaneous and active in listening while one of the students narrated a story in Savara language. Some children laughed and others were speaking to the child sitting next to them. Children had difficulty in narrating the same story in Telugu. Participation of the students and interaction was low when the students narrated the story in Telugu, which required one to translate and frame the words, and the listeners were also slow in their response as they had to understand and internalize and frame the response.

Government supplied text books in Savara dialect, but they are not being used. Since two years the text books are lying in one corner of a class room. Use of text books in Savara dialect and teaching in mother tongue of the tribal children was not reviewed. Teacher was not aware of any training in use of local dialects.

\section{MLE - Needs of Tamil Community in Nellore District}

Tamil is the major language spoken in border villages of Tada mandal. Very few adults can speak Telugu. Tamil community in the border villages of Nellore consider themselves distinct from the dominant cultural fabric of Nellore district. There is growing pressure from the community to open Tamil medium schools or at least include Tamil as one subject. Children of Tamil community are slowly learning to speak Telugu if they are studying in local government schools. However, a section of the Tamil population are sending their children to the Tamil medium schools run by the private institutions or the government across the border which is not very far from Tada.

Since there are no government schools in Tamil medium, these children have no choice but to study in Telugu. Teachers have no exposure to the local language and play little role in promoting inclusive education. Some Tamil households are leaving the local government schools and attend Tamil medium schools.

\footnotetext{
Difficult to make school attractive to the linguistic minorities- Tamil islands in Nellore

Ramapuram MPUPS has four class rooms for a strength of 133 (85 boys and 48 girls), of whom 115 (69 boys and 46 girls) were present on the day of field study. School also has a room for teachers, a kitchen, office room and four toilets. There are three UPS and four Primary Schools in Ramapuram MPUPS School Complex.

Tada mandal has some pockets of exclusively Tamil speaking habitations. Ramapuram School Complex villages are all Tamil speaking habitations except Kavalimitta where inhabitants are Telugu speaking. Five schools in Tada mandal have been closed in the last four years because of language and quality concerns. Locally, there are several private English medium schools and also Tamil medium schools. Saint Mary Matrulaxmi Higher Secondary School (Tamil medium) in the neighborhood has 1600 strength. They are also asking for starting a Tamil medium school, but the government has not yet approved the request.

Most of the Tamil speaking people are illiterate. They are wage labour in companies, and have no time to be at home or look after the children. About $80 \%$ of the families are fisher folk. They speak only Tamil. About $10 \%$ are from SC whose children have learnt to speak Telugu and the remaining $10 \%$ are Yanadi Scheduled Tribe. Adults among Yanadis speak only Telugu while their children can speak both Telugu and Tamil.
} 


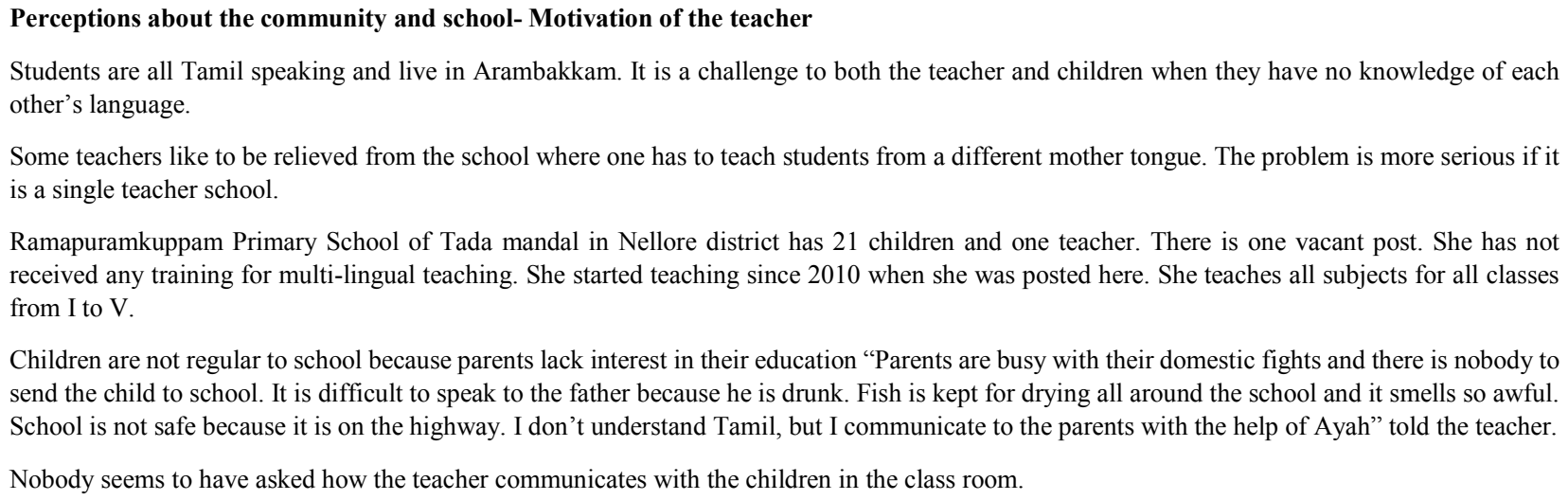

Ramapuramkuppam Primary School of Tada mandal in Nellore district has 21 children and one teacher. There is one vacant post. She has not received any training for multi-lingual teaching. She started teaching since 2010 when she was posted here. She teaches all subjects for all classes from I to $\mathrm{V}$.

Children are not regular to school because parents lack interest in their education "Parents are busy with their domestic fights and there is nobody to send the child to school. It is difficult to speak to the father because he is drunk. Fish is kept for drying all around the school and it smells so awful. School is not safe because it is on the highway. I don't understand Tamil, but I communicate to the parents with the help of Ayah" told the teacher.

Nobody seems to have asked how the teacher communicates with the children in the class room.

Some teachers believe that it is better to avoid use for local language so that the children learn faster to speak Telugu. There are unwritten rules of limiting or suppressing use of local dialects and languages. Ramapuram MPUPS in Tada mandal has a rule that children from Class II should not speak in their mother tongue. There was no Language Pandit (Telugu) till 2012.

Many children from Tada mandal on the border of Tamil Nadu are going to Tamil medium schools of neighboring state. Those schools are more attractive because they get free bags, foot wear, books and pens, and egg is served every day in MDM.

\section{MLE in Kadapa}

Muslims constitute a small section of Kadapa and speak Urdu. But they are also equally fluent and comfortable with Telugu. Challenges and concerns of Urdu speaking minorities are not culturally distinct like Tamilians, Oriya or Savara tribe. Telugu spoken locally is slightly different from the language used in the text books and the language of the Radio lessons.

Peddabidiki Primary School, established in 1973, of Sambepalli mandal in Kadapa district has 43 students enrolled, of which 36 were present on the day of the field study. Of the two teachers appointed, one was on leave.

Village has a population of about 1000 and most of them are literate. Around 200 have migrated abroad for jobs. Only old people and children of farming households are in the village The school in Parakalabanda, adjacent to this village, was closed because a private school has come up in the neighbourhood. Absenteeism and household pressures to assist in domestic chores is a major problem for retention and learning achievement of the children.

\section{Conclusions}

Field study reveals the importance of building a culturally responsive inclusive education system that guides redesigning of school curriculum while focusing on MLE, in order to meet the expectations of these communities.

Practice of MLE is a tool for inclusive education in border areas especially where the inhabitants speak languages different from state official language. Three districts present diverse scenarios of the challenges and responses of the government schools to make schools more inclusive and culturally responsive.

Choice of school and access to education in one's mother tongue is observed to be determined by several factors purpose of education, level of education, importance of medium of instruction in selection for government jobs, etc. It is also dependent on what the level of education one expects to achieve -up to elementary school, high school, college education or beyond. Many of these perceptions are also influenced by how much a household is prepared to invest in the child's education. Outcomes of these choices affect one's right to education in one's mother tongue.

Certain linguistic minorities, like Tamilians and Oriya, prefer to study in their mother tongue instead of Telugu -the state official language. There is strong demand for MLE in Srikakulam and Nellore to meet expectations of the Tamil and Oriya communities in these districts respectively. Demand for teaching in Savara tribal language in Srikakulam district is not visible as the numerical strength of the tribe is low as well as its poor role in the local power structure. Savara children who are not so keen or aware about government jobs or higher education are accepting the local Telugu medium government schools. Nellore has intense competition from Tamil medium schools run by private institutions and the neighbouring government schools. They are accessed by the Tamil speaking people of Nellore because of shorter distance, and road connectivity. Tamil households interested in government jobs in Tamil Nadu prefer to study in government or private Tamil medium schools. Kadapa has issues of inclusive education common to any other district and are mainly related to gender, lack of cooperation of the parents, poverty and threat of losing more students to private schools. Demand for teaching in Urdu is not strong in Kadapa as the Muslim households consider it is better to study in Telugu medium schools to compete effectively for admissions in educational institutions or jobs. 
Alternative schools offering Urdu, Telugu or English medium are limited in Kadapa.

Many Oriya boys than girls are studying in Telugu medium schools in Srikakulam. Girls are seen studying in Oriya medium because they are not likely to study beyond primary school or high school and are also likely to marry someone from the neighbouring state. Some Oriya boys go to government or private Telugu medium schools.

There are unwritten rules of limiting the use of local dialects and languages, as part of the "hidden curriculum" of schools catering to linguistic minorities.

The diverse situation highlights that some linguistic communities are more resilient and strong to retain their language than others. While the Savara tribe in Srikakulam is weak and smaller in number to insist on the implementation of Savara language in schools, the Oriya community is trying its best to continue Oriya medium at least at lower level of schooling. Tamil community is continuing to study in their mother tongue in private or government schools within the state or in neighbouring state across borders, as there are no government schools offering Tamil medium in Andhra Pradesh.

\section{Acknowledgements}

The author is grateful to the support of Save the Children India for conducting the field research.

\section{REFERENCES}

APACR (2014). Study Report on the Implementation of Right to Education Act, 2009 in the state of Andhra Pradesh, Hyderabad.

Devanoora Mahadeva (2015). Who Is Killing Our Languages?, Outlook, March 9, 2015

Devasena. K (2007). "Learning among the students of Tamil mother tongue and Telugu in areas with Tamil influence", SSA-AP, Hyderabad.

Durkheim, E (1922), Education and Sociology, transl., and with an introduction, by Sherwood D. Fox, Foreword by Talcott Parsons, New York, The Free Press, 1956, p.71, translated from the French: Education et sociologie, Paris, Presses Universitaires de France, 1989.

Gerth, H.H \& Milks, C.S. (ed) (1947). Politics as a Vocation in 'From Max Weber'.

Global Education Monitoring Report (2016). If you don't understand, how can you learn? Policy Paper 24, GEMRUNESCO.http://unesdoc.unesco.org/images/0024/002437/243713 E.pdf.

GOAP-SSA (2015): State Level Achievement Survey 2014-15. A Study on Learning Levels of Students Studying Class III and Class VIII in Andhra Pradesh- A Report, Hyderabad.

GOAP-SSA (May 2014). Strategy Document on Inclusion in Education- Andhra Pradesh.
Govinda and Bandyopadhyay (2008) Access to Elementary Education in India, CREATE.

http://www.create-rpc.org/pdf_documents/India_CAR.pdf

Hari Prasad D (2005). "Promotion of Telugu language ability among the tribal children", SSA-AP, Hyderabad.

Jha and Jhingram. (2005). 'National Focus Group on the Problems of Scheduled Castes and Scheduled Tribes'. National Council for Education Research and Training (NCERT), New Delhi.

Kumar, Krishna. (1989). 'Social Character of Learning'. Sage Publications, New Delhi, 1989.

Lingaiah P and Ashok (2010). "A study on performance of children in tribal welfare and other schools in Adilabad district", SSA-AP, Hyderabad.

Mac Iver \& Page -Society: An Introductory Analysis, 1949, p. 456.

MacKenzie, P.J (2009). Mother tongue first multilingual education among the tribal communities in India, International Journal of Bilingual Education and Bilingualism Vol. 12, Issue. 4, 2009.

Mallikarjun, Y (2015). Students taught in mother tongue perform better at primary school level, The Hindu 14 December, 2015.

Multilingual Education, Working Group- Asia Pacific (2009). Andhra Pradesh- MLE Status Report. http://www.asiapacificmle.n et/wp-content/uploads/2013/03/Andhra-Pradesh-MLE-status-repor t.pdf.

Nambissan, Geetha B. (1994). 'Language and Schooling of Tribal Children: Issues Relating to the Medium of Instruction', Economic and Political Weekly XXIX (42), 1994, 2747-54.

Narender Reddy (2014). "Study on the effectiveness of MLE method in achieving language skills in Banjara children at Primary Level", SSA-AP, Hyderabad.

Patton, M. (2011). Developmental evaluation: Applying complexity concepts to enhance innovation and use. New York, NY, The Guilford Press.

Sadgopal, Anil (2006). A Post-Jomtien Reflection on the Education Policy: Dilution, Distortion and Diversion, in The Crisis of Elementary Education in India (Ed. Ravi Kumar), SAGE Publications, New Delhi.

Sadgopal, Anil (2014). Education system based on inequality: Sadgopal, The Assam Tribune, 4 November 2014.

SSA- AP. 'Mother Tongue based Multilingual Education in Adivasi Oriya, Banjara, Rajkoya (Gondi), Kolavar (Kolami), Konda, Koya, Kuvi and Sora (Savara)'.

SSA- AP. 'The comfortability and impact of class ii tribal primers and Classes I \& II Mathematics Textbooks'.

SSA- AP. A paper on Multilingual Education- Tribal languages as Media of Instruction.

Sujatha, K (2012). Multilingual Education- Innovation for improving quality of learning, National Workshop on Innovative Practices in School Education, held on 9-10 November, 2012 at Vishakapatnam, organised by Centre for Innovation in Public Systems (CIPS), Hyderabad.

The Hindu (2008). 'Help Telugu medium schools in other States', December 27, 2008. 
UNESCO (2004). Embracing Diversity- Tool kit for Creating Inclusive, Learning- friendly Environments, Thailand.

UNESCO (2009). Policy Guidelines on Inclusion in Education. UNESCO: Paris. http://unesdoc.unesco.org/images/001.
Young Lives (2013). Need for Systemic Reform in Education: Ensuring Poorest Children Are Not Short-changed! India Policy Briefs, No. 1

http://www.younglives-india.org/files/policy-papers/need-for-syste mic-reform-in-education 